\title{
AOR
}

Selected Papers of \#AolR2019:

The $20^{\text {th }}$ Annual Conference of the Association of Internet Researchers Brisbane, Australia / 2-5 October 2019

\section{FROM KNOWLEDGE CATHEDRALS TO NETWORKED CO-CREATION: PUBLIC LIBRARIES, TRUST, AND THE KNOWLEDGE ECONOMY}

\author{
Danielle Wyatt \\ University of Melbourne \\ Dale Leorke \\ Tampere University
}

\begin{abstract}
Since their emergence in the mid-nineteenth century, public libraries have been trusted sites of information. As enlightenment institutions, built upon the authority of the book (Billington 1998), the public trust they enjoy has been predicated on their standing as foundational institutions of the public sphere. For Habermas, the public sphere is a space of 'undistorted communication' (Audunson 2005, 434) independent from the market and the state. Libraries were funded by philanthropists and governments to provide an independent space for the accumulation of knowledge. Historically, they have been valued for promoting rational discourse and higher learning, and for giving citizens access to the materials they need for informed, democratic participation in society.

Libraries have retained this public trust even as the networked society and digital technologies have profoundly changed the status and function of information in social and economic life (Sassen 2002; Castells 2002). Information super-abundance (McCullough 2013), 'platform capitalism' (Srnicek 2017) and the rise of 'big data' (Kitchin, 2014) have made information a currency within increasingly intersecting processes of commercial exchange, governance, surveillance and self-expression. Libraries are not on the sidelines of this shift. As media centres and information managers, they have supported users to navigate the new ways information is distributed and accessed. They are also actively shaping how information is put-to-use, reconfiguring their service delivery around user-centred models emphasising participation and co-creation of content, user experience, pleasure, innovation, and peer-to-peer learning.
\end{abstract}

Wyatt, D. and D. Leorke (2019, October 2-5). From Knowledge Cathedrals to Networked Co-creation: Public libraries, trust, and the knowledge economy. Paper presented at AolR 2019: The $20^{\text {th }}$ Annual Conference of the Association of Internet Researchers. Brisbane, Australia: AoIR. Retrieved from http://spir.aoir.org. 
This paper explores the tensions at the heart of the library's continued status as a site of public trust and source of trusted information. Using a theoretically contextualised ethnographic methodology, the paper discusses how libraries perform as infrastructures of trust in the knowledge economy - a time of both opportunity and disruption. Our research is premised upon social studies of science and technology approaches to digital technologies. As Judy Wajcman (2002) has argued, new technologies do not flow unmediated into everyday practices. Social studies of science and technology, she argues, 'provides rich resources for understanding technology as a socio-technical product, patterned by the relations of its production and use' (360). Libraries are relevant, but often overlooked institutions in wider debates around the internet and the impact of digital technologies on communication, connectivity and public discourse. They are 'meso-level' (Mansell 2002) sites that support digital information infrastructures and embed them into social life. As a widely distributed network, accessible to all sectors of society, libraries redistribute digital capacity to excluded populations (Wyatt et al 2018), as well as facilitating adaptation to and normalisation of these technologies within very different communities and professional sectors.

Part one of the paper contextualises the library's altered relation to information within its physical transformation as an institution. In response to the rise of networked, digital technologies, libraries have reinvented themselves from the silent cathedrals of knowledge of the Carnegie era, to more diversified, programmable spaces of noise and activity (Mattern 2007; 2014). They have become entrepreneurial hubs, community centres, training facilities, innovation labs and makerspaces, hosting everything from coding workshops for children, to business startups, to community choirs and book clubs. Coupling striking architectural design with attention to ambience and comfort, libraries have signaled their desire to be both engines of innovation and creative production, and hearts of community life (Leorke and Wyatt 2019).

Part two drills down into how libraries perform as infrastructures of informational trust by drawing from qualitative interviews with library professionals from Australian libraries across Victoria and Queensland. The experiences of library managers, IT professionals, architects and policymakers reveal that libraries continue to see themselves in the frame of their enlightenment inheritance as mediators of truth, knowledge and rational discourse. They see a role for themselves in educating the public in news and information literacy, and in distinguishing between authentic news and 'fake news'. They run programs with children around cyber-safety and who to trust online. And they are spaces for informed debate, encouraging open discussion on topical or contentious issues.

At the same time, these libraries are promoting very different informational values. As Stephen Sayers, Manager of Digital Experience at the State Library of Victoria explains: 'Our current strategy, number one, is people at the heart. And I think the digital experience encapsulates that, that it's all about what users would like to do or the experience that users would like to have with technology' (Sayers transcript 2017). With users 'at the heart' of their service, libraries are shifting their focus from being spaces for the storage and consumption of information, to being spaces of creation and creativity. They are investing in programs to stimulate innovation and entrepreneurial 
activity, and seeking to connect users to networks through which they can develop their ideas and capacity, often for commercial applications.

Libraries continue to value and maintain their (increasingly digitized) collections. But our research reveals a change in how libraries perform as trusted institutions: from repositories conferring institutional legitimacy upon information (Billington 1998), to 'platforms' (Weinberger 2012) that legitimate the processes through which users navigate and make productive use of an expanded informational field. This shift cannot be detached from broader, neoliberal, technology-driven visions of the knowledge economy. Libraries globally have embraced the underlying agendas of the knowledge economy, positioning themselves as support infrastructure to transition citizens into digitally literate, entrepreneurial agents who can compete in the precarious conditions of a globalized, post-industrial labour market.

The reinvented library is a long way from being the 'collective communal tribute to the culture of the book' (Billington 1998, 12) that made it a trusted institution for much of its history. Instead, our findings reveal that libraries perform as institutions of informational trust in a variety of non-equivalent ways. They promote themselves as trusted mediators of truth and knowledge in the public sphere, while also embracing the expanded participatory and creative potential of new technologies and new media. The tensions between these roles suggests that we need to develop new thinking around what kind of trust infrastructures we need in an information-abundant, entrepreneurialist culture.

\section{References}

Audunson, R. (2005) The Public Library as a Meeting-Place in a Multicultural and Digital Context. Journal of Documentation 61(3): 429-441.

Billington, J. (1998). American Public Libraries in the Information Age: Constant Purpose in Changing Times. Libraries \& Culture 33(1): 11-16.

Castells, M. (2002) An Introduction to the Information Age. In Gary Bridge and Sophie Watson, eds, The Blackwell City Reader. Oxford: Blackwell Publishing.

Kitchin, R. (2014) The Data Revolution. London: SAGE.

Leorke, D. and D. Wyatt (2019) Public Libraries in the Smart City. Palgrave.

Mansell, R. (2002) From digital divides to digital entitlements in knowledge societies. Current Sociology 50(3): 407-426.

Mattern, S. (2007). The New Downtown Library: Designing with Communities. Minneapolis: University of Minnesota Press.

Mattern, S. (2014, June). Libraries as Infrastructure. Places Journal. https://placesjournal.org/article/library-as-infrastructure/. 
McCullough, M. (2013) Ambient Commons: Attention in the Age of Embodied Information. MIT Press

Sassen, S. (2002) Towards a Sociology of Information Technology. Current Sociology. 50(3): 365-388.

Srnicek, N. (2017) Platform Capitalism. Polity Press.

Wajcman, J. (2002) Addressing Technological Change: The Challenge to Social Theory. Current Sociology 50(3): 347-363.

Weinberger, D. (2012) Library as Platform. Library Journal. https://www.libraryjournal.com/?detailStory=by-david-weinberger

Wyatt, D., S. McQuire and D. Butt (2018) Libraries as redistributive technology: from capacity to culture in Queensland's public library network. New Media and Society, 20(8): 2934-2953. 